\title{
PENGARUH KONSELING KELOMPOK DENGAN PENDEKATAN BODY IMAGE-COGNITIVE BEHAVIORAL THERAPY (BI-CBT) TERHADAP SISWI SMK YANG MEMILIKI CITRA TUBUH NEGATIF
}

\author{
Susi Fitri ${ }^{1}$ \\ Aip Badrudjaman ${ }^{2}$ \\ Nurul Fazriah ${ }^{3}$
}

\begin{abstract}
Abstrak
Penelitian Quasi eksperimen ini bertujuan untuk mengetahui pengaruh layanan konseling kelompok dengan pendekatan Body Image Cognitive Behavioral Therapy (BI-CBT) terhadap Siswi kelas XI di SMK Negeri 1 Babelan yang Memiliki Citra Tubuh Negatif. Sampel dalam penelitian ini adalah siswa kelas XI SMK Negeri 1 Babelan sebanyak 6 orang pada kelompok tretment dan 6 orang pada kelompok kontrol. Pengambilan sampel menggunaakan teknik purposive sampling. Metode yang digunakan adalah metode eksperimen, dengan desain Quasi experimental design dan bentuk desain Non-equivalent Control Group Design. Pengumpulan data dilakukan dengan menggunakan kuesioner MBSRQ dan dianalisis menggunakan Wilcoxon Sign Rank Test. Hasil analisis menunjukkan nilai sig. $=0.028$ pada kelompok treatment yang berarti nilai probabilitas lebih kecil dari nilai signifikansi $\alpha=0.05$, dengan demikian dapat disimpulkan bahwa HO ditolak dan HI diterima. Hasil analisis dapat diartikan bahwa Konseling kelompok pendekatan Body Image Cognitive Behavioral Therapy (BI-CBT) berpengaruh terhadap body image siswi kelas XI di SMK Negeri 1 Babelan. Siswi yang telah mengikuti Konseling kelompok dengan pendekatan Body Image Cognitive Behavioral Therapy (BI-CBT) dapat memahami dirinya dan mengendalikan pola pikir serta perasaannya terhadap caranya memandang dirinya dan tanggapan dari orang lain. Hal tersebut membuat siswi menjadi lebih mampu untuk menerima diri dan tampil lebih percaya diri.
\end{abstract}

Kata kunci: Konseling Kelompok, Body Image Cognitive Behavioral Therapy

\begin{abstract}
Abtract
This quasi experimental research aims to determine the effect of group counseling service with Body Image Cognitive Behavioral Therapy (BI$C B T$ ) approach towards students at the eleventh grade in SMK Negeri 1 Babelan which have a negative body image. The samples of this research

1. Dosen Program Studi Bibingan dan Konseling FIP UNJ, susi.fitri.kuliah@gmail.com

2. Dosen Program Studi Bibingan dan Konseling FIP UNJ, aip_bj@yahoo.com

3. Mahasiswa Program Studi Bimbingan dan Konseling FIP UNJ, Nurul.fazriah.kuliah@gmail.com
\end{abstract}


were students at the eleventh grade in SMK Negeri 1 Babelan; six students for treatment group and six students for control group. The samples were taken by using purposive sampling technique. The method was experimental method, with Quasi Experimental as the design and Nonequivalent Control Group Design as the design form. The data were collected by using MBSRQ Questionnaire and the data were analyzed by using Wiloxon Sign Rank Test. The result of the test shows that value of sig. $=0.028$ in treatment group it means the probability value is smaller than significant value $\alpha=0.05$, it can be concluded the $H O$ was rejected and $H 1$ was accepted. Analysis results can be interperted that group counseling Body Image Cognitive Behavioral Therapy (BI-CBT) approach has effect toward the improvement of students body image at the eleventh grade in SMKN 1 Babelan. The students who have attended group counseling with Body Image Cognitive Behavioral Therapy (BI-CBT) approach could figure out himself and control the paradigm and feelings for the way of looking at himself and the others responses. This makes students more able to accept themselves and be confident.

Keywords: Group Counseling, Body Image Cognitive Behavioral Therapy

\section{PENDAHULUAN}

Citra tubuh (body image) sebagai salah satu dari konsep diri adalah sikap seseorang terhadap tubuhnya secara sadar dan tidak sadar. Sikap ini mencakup persepsi dan perasaan tentang ukuran, bentuk, fungsi penampilan dan potensi tubuh saat ini dan masa lalu yang secara berkesinambungan dimodifikasi dengan pengalaman baru setiap individu (Stuart and Sundeen, 1995). Shilder mengemukakan bahwa body image merupakan gambaran mengenai tubuh seseorang yang terbentuk dalam pikiran individu itu sendiri, atau dengan kata lain gambaran tubuh individu menurut individu itu sendiri (Grogan, 2008). Dari berbagai permasalahan body image yang paling umum adalah masalah ketidakpuasan terhadap citra tubuh.

Penampilan fisik seseorang berpengaruh terhadap bagaimana orang lain mempersepsikan dan berinteraksi dengan dirinya. Remaja yang tidak puas terhadap penampilannya akan memandang diri mereka tidak cantik atau kurang menarik penampilan fisiknya akan menerima evaluasi negatif dari teman dan mengurangi kontak sosial (Gayatri, 2011). Ketidakpuasan berarti ketidaksukaan individu terhadap tubuhnya atau bagian-bagian tubuh tertentu. Besarnya kesenjangan antara citra tubuh ideal dengan citra tubuh nyata merupakan indikator adanya ketidakpuasan terhadap sosok tubuh. Distorsi citra tubuh adalah ketidakmampuan menilai ukuran tubuh secara akurat, akibat kesenjangan antara keadaan tubuh nyata dan keadaan tubuh yang ada dalam pikiran seseorang. Seseorang bisa saja mengatakan tubuhnya "jelek", saat orang lain menganggap bahwa sebenarnya ia cukup menarik. Bentuk tubuh tinggi dan langsing merupakan hal yang diinginkan oleh remaja putri. Pada kenyataannya, banyak remaja putri yang merasa tidak puas dengan tubuhnya karena ketidaksesuaian ukuran tubuhnya dengan ukuran tubuh yang diinginkan (Mahan, 2008). Ketidakpuasan yang dirasakan oleh remaja perempuan mengenai citra tubuh dirinya menjadikan individu tersebut memiliki citra tubuh negatif.

Permasalahan terkait citra tubuh dapat diselesaikan menggunakan beberapa pendekatan. Cash mengungkapkan bahwa citra tubuh dapat diselesaikan dengan manggunakan pendekatan Body image Cognitive Behavior Therapy (BI-CBT). BI-CBT ditetapkan secara jelas sebagai treatment yang efektif untuk 
gangguan citra tubuh karena bertujuan untuk memodifikasi pikiran yang irasional, perasaan, dan perilaku melalui intervensi seperti psikoedukasi, pemantauan diri, rekonstruksi kognitif, dan desentralisasi (Cash, 2011).

Cognitive Behavior Therapy (CBT) adalah suatu bentuk intervensi psikologis yang bertujuan untuk membantu individu mengenali, mendahulukan, dan menghubungkan pikiran, perasaan, dan simptom fisik dengan menggunakan teknik kognitif dan behavior (Anderson, Watson, \& Davidson, 2008). Pendetakan CBT terus berkembang dan sudah banyak peneliti yang melakukan penelitian dengan pedekatan CBT, seperti yang dilakukan oleh Gema Maulidina.

Penelitian yang telah dilakukan oleh Gema Mauludina pada tahun 2012 tentang pengaruh kelompok psikoedukasi dengan cognitive behavioral therapy (CBT) terhadap Body Image negatif pada siswi kelas X SMAN 32 Jakarta, menghasilkan bahwa terdapat pengaruh positif pada kelompok psikoedukasi dengan CBT terhadap body image. Dengan penelitian ini semakin membuktikan bahwa CBT dapat digunakan untuk menyelesaikan permasalahan terkait citra tubuh. Selain itu, banyak juga penelitian internasional yang mengangkat tema mengenai citra tubuh.

Berdasarkan studi pendahuluan yang telah dilakukan di SMK Negeri 1 Babelan yang dilakukan dengan menyebar angket kualitatif kepada 20 orang siswi didapatkan hasil bahwa $70 \%$ siswi merasa bahwa ia tidak memiliki bentuk tubuh dan wajah yang menarik dan masih sering membandingkan penampilan dirinya dengan teman-temannya sehingga membuat ia sering tidak percaya diri. Para siswi menyadari bahwa penampilan sangat penting untuk menunjang kehidupan mereka setelah lulus sekolah sehingga banyak dari mereka yang merasa perlu memperbaiki penampilan dirinya. Karakteristik SMK Negeri 1 Babelan yang berciri Industri otomotif membuat peserta didiknya didominasi oleh laki-laki. Sehinngga bagi perempuan yang berada pada lingkungan yang maskulin atau lebih banyak laki-laki akan membuat mereka lebih memperhatikan penampilan dirinya agar terlihat lebih menarik dihadapan lawan jenisnya, atau justru cenderung berkeinginan untuk tampil menyerupai lakilaki untuk meningkatkan kepercayaan dirinya.

Berdasarkan uraian di atas maka peneliti ingin meneliti lebih lanjut bagaimana pengaruh penerapan pendekatan body image cognitive behavior therapy (BI-CBT) terhadap Body Image negatif pada siswi di SMK Negeri 1 Babelan.

\section{ACUAN TEORITIK}

\section{Definisi Citra Tubuh}

Citra tubuh menurut Grogan adalah persepsi, pikiran dan perasaan seseorang tentang tubuhnya (Grogan, 2008). Shilder mengartikan citra tubuh sebagai gambaran mengenai tubuh seseorang yan terbetuk dalam pikiran individu itu sendiri, atau dengan kata lain gambaran tubuh individu menurut individu itu sendiri (Grogan, 2008). Pengertian tersebut di perkuat oleh pendapat yang menyatakan bahwa citra tubuh merupakan representasi mental dari tubuh yang meliputi persepsi dari penampilan, perasaan dan pikiran tentang tubuh, bagaimana rasanya berada di dalam tubuh, dan fungsi tubuh dan kemampuannya (Cash \& Pruzinsky, 2002).

Citra tubuh ada dua macam, yaitu positif dan negatif. Seorang perempuan dengan citra tubuh positif memiliki sebuah persepsi yang nyata terhadap ukuran dan bentuk tubuhnya, dan merasa nyaman dengannya. Sementara perempuan dengan citra tubuh negatif memiliki pemahaman yang menyimpang mengenai bentuk tubuh dan ukuran tubuhnya.

\section{Komponen Citra Tubuh}

Citra tubuh terdiri dari 10 kategori. Thomas F. Cash. menjabarkan terdapat 
sepuluh aspek yang menjelaskan citra tubuh (Cash, 2000), yaitu sebagai berikut:

1. Evaluasi Penampilan (Appearance Evaluation). Mengukur perasaan menarik atau tidak menarik, kepuasaan atau ketidakpuasaan terhadap penampilan seseorang. Skor tinggi berarti memiliki perasaan puas terhadap penampilan sedangkan skor rendah menggambarkan ketidakpuasaan terhadap penampilan fisiknya.

2. Orientasi Penampilan (Appearance Orientation). Orientasi penampilan (appearance orientation) mengukur derajat perhatian individu terhadap penampilannya. Individu dengan skor tinggi menempatkan penampilan sebagai hal yang penting diwujudkan dalam bentuk perawatan tubuh dan penataan penampilan fisik.

3. Evaluasi Kebugaran (Fitness Evaluation). Evaluasi kebugaran (fitness evaluation) mengukur derajat kebugaran yang dirasakan individu terhadap fisiknya. Individu dengan skor tinggi menilai dirinya bugar, berada dalam kondisi yang baik, memiliki kompetensi fisik dan kemampuan atletik yang baik.

4. Orientasi Kebugaran Fisik (Fitness Orientation). Orientasi kebugaran fisik (fitness orientation) mengukur derajat perhatian individu terhadap kebugaran atau kompetensinya dalam bidang olah raga. Individu dengan skor tinggi menilai kebugaran sebagai hal yang penting dan secara aktif mengikuti kegiatan fisik untuk meningkatkan atau mempertahankan kebugaran. Individu dengan skor rendah tidak menilai penting kebugaran sehingga tidak melakukan usaha dan tidak aktif mengikuti kegiatan fisik untuk meningkatkan atau mempertahankan kebugaran.
5. Evaluation Kesehatan (Health Evaluation). Evaluation kesehatan (Health Evaluation) mengukur penilaian individu mengenai kesehatan tubuhnya. Individu dengan skor tinggi merasa tubuhnya berada pada kondisi prima dan bebas dari penyakit. Individu dengan skor rendah tidak merasa sehat atau sedang merasa gejala-gejala penyakit, atau merasa dirinya rentan terhadap penyakit.

6. Orientasi Kesehatan (Health Orientation). Orientasi kesehatan (health orientation) mengukur derajat pengetahuan dan kesadaran individu terhadap pentingnya kesehatan fisik. Individu dengan skor tinggi sangat memperhatikan kesehatannya dan memiliki pengetahuan yang cukup tentang kesehatan sehingga selalu berusaha untuk mengembangkan gaya hidupsehat. Individu dengan skor rendah lebih apatis terhadap kesehatannya dan tidak memiliki pengetahuan yang cukup tentang kesehatan.

7. Orientasi tentang Penyakit (Illness Orientation). Orientasi tentang penyakit (illness orientation) mengukur derajat pengetahuan dan reaksi individu terhadap berbagai masalah penyakit yang dirasakan tubuh. Individu dengan skor tinggi sangat sadar terhadap gejalagejala penyakit dan segera berusaha mencari pengobatan. Individu dengan skor rendah tidak mempunyai kesadaran terhadap keadaan tubuh bila terserang penyakit dan tidak reaktif terhadap gejala penyakit.

8. Kepuasaan Area Tubuh (Body Areas Satisfaction Scale). Kepuasaan area tubuh (Body areas satisfaction scale) mengukur kepuasan individu terhadap aspek-aspek tertentu dari penampilan. Skor tinggi menunjukan kepuasaan terhadap sebagian besar area tubuh. 
9. Kecemasan terhadap Kegemukan (Overweight Preoccupation). Kecemasan terhadap kegemukan (overweight preoccupation) menggambarkan persepsi seseorang terhadap berat badannya, kecemasan terhadap kegemukan, perhatian terhadap berat badan, kecenderungan melakukan diet untuk menurunkan berat badan dan membatasi pola makan.

10. Pengkategorian ukuran tubuh (self classified weight). Pengkategorian ukuran tubuh (self classified weight) menggambarkan bagaimana seseorang mempersepsikan dan menilai berat badannya.

\section{Faktor- faktor yang Mempengaruhi} Permasalahan Citra Tubuh

Cash mengungkapkan bahwa pada masa puber terdapat tantangan perkembangan yang mempengaruhi citra tubuh remaja, seperti seksualitas, pembentukan identitas, peran gender yang kuat dan pencarian kemungkinan realistik untuk mencapai kesuksesan (Cash, 2001). Hal tersebut membuat transisi remaja perempuan lebih sulit daripada remaja laki-laki karena disaat yang sama remaja perempuan juga melakukan banyak perlawanan terhadap berat tubuh, masa berpacaran, dan adaptasi memasuki usia sekolah menengah (Cash, 2001). Citra tubuh kemudian menjadi salah satu sasaran remaja perempuan untuk merealisasikan gambaran tubuh yang idealnya. Meskipun dalam usaha remaja untuk merealisasikan hal tersebut terbentur oleh keterbatasan terkait faktor-faktor yang mempengaruhi perkembangan citra tubuh.

Beberapa ahli menyatakan bahwa citra tubuh dapat dipengaruhi oleh beberapa faktor. Faktor-faktor yang mempengaruhi citra tubuh antara lain: jenis kelamin, media massa, hubungan interpersonal, dan kepribadian seseorang.

\section{Definisi BI-CBT}

Gangguan emosi yang mengakibatkan pikiran negatif pada citra tubuh dapat diselesaikan dengan menerapkan pendekatan Body-image cognitive behavior therapy (Cash, 2011). Pada umumny individu yang memiliki citra tubuh negatif meras dirinya tidak berharga dibanding orang lain, padahal citra tubuh yang ia pikirkan tentang dirinya belum tentu sama dengan persepsi individu tersebut tentang dirinya. Penelitian yang dilakukan oleh Jarry dan Berardi pada tahun 2004 kepada mahasiswa perempuan yang menunjukan bahwa penerapan BI-CBT efektif untuk meningkatkan dimensi citra tubuh serta kesejahteraan psikologis seperti kecemasan, depresi, dan self-esteem membaik. Namun meskipun pengukuran citra tubuh dengan BI-CBT dapat berpengaruh, hasil yang lebih signifikan bisa didapat dengan menerapkan intervensi BI-CBT (cash, 2011).

Hrabosky dan cash mengatakan bahwa intervensi terdiri dari psychoeducation yang dikombinasikan dengan sistematis self-monitoring ini efektif jika ditambah komponen restrukturisasi kognitif. BICBT dapat diterapkan dengan mengajak individu mengevaluasi dirinya kemudian mengkronfrontasi pemikiran-pemikiran irrasional individu terkait citra tubuhnya, kemudian mengevaluasi bukti butkti yang membuat indiviidu berpikir negatif. Setelah pikiran yang negatif dievaluasi maka saatnya untuk mengubah pikiran negatif menjadi pikiran positif. 


\section{Tujuan BI-CBT}

BI-CBT bertujuan memodifikasi disfungsional pikiran, perasaan, dan perilaku melalui intervensi berbagai teknik. Garber mengatakan bahwa tujuan dari BI-CBT adalah untuk mengajak menjadi realistis dalam menafsirkan situasi yang cenderung memicu pola pikir negatif. Dengan menjadi lebih sadar dengan akan kekuatan pikirannya kemampuan individu akan dapat dikembangkan dan dimanfaatkan untuk mengatasi berbagai masalah cutra tubuh negatif(Garber, 2015).

Tujuan dari cognitive behavior therapy yaitu mengajak konseli untuk menentang pikiran dan emosi yang salah dengan menampilkan bukti-bukti yang bertentangan dengan keyakinan mereka tentang masalah yang dihadapi. Konselor diharapkan mampu menolong konseli untuk mencari keyakinan yang sifatnya dogmatis dalam diri konseli dan secara kuat mencoba menguranginya (Oemarjoedi, 2003).

\section{Prinsip Konseling CBT}

Berikut adalah prinsip-prinsip dasar dari CBT:

Prinsip nomor 1: Cognitive-Behavior Therapy didasarkan pada formulasi yang terus berkembang dari permasalahan konseli dan konseptualisasi kognitif konseli.

Prinsip nomor 2: Cognitive-Behavior Therapy didasarkan pada pemahaman yang sama antara konselor dan konseli terhadap permasalahan yang dihadapi konseli.

Prinsip nomor 3: Cognitive-Behavior Therapy memerlukan kolaborasi dan partisipasi aktif.

Prinsip nomor 4: Cognitive-Behavior
Therapy berorientasi pada tujuan dan berfokus pada permasalahan.

Prinsip nomor 5: Cognitive-Behavior Therapy berfokus pada kejadian saat ini.

Prinsip nomor 6: Cognitive-Behavior Therapy merupakan edukasi, bertujuan mengajarkan konseli untuk menjadi terapis bagi dirinya sendiri, dan menekankan pada pencegahan.

Prinsip nomor 7: Cognitive-Behavior Therapy berlangsung pada waktu yang terbatas.

Prinsip nomor 8: Sesi Cognitive-Behavior Therapy yang terstruktur. Struktur ini terdiri dari tiga bagian konseling. Bagian awal, menganalisis perasaan dan emosi konseli, menganalisis kejadian yang terjadi dalam satu minggu kebelakang, kemudian menetapkan agenda untuk setiap sesi konseling. Bagian tengah, meninjau pelaksanaan tugas rumah (homework asigment), membahas permasalahan yang muncul dari setiap sesi yang telah berlangsung, serta merancang pekerjaan rumah baru yang akan dilakukan. Bagian akhir, melakukan umpan balik terhadap perkembangan dari setiap sesi konseling. Sesi konseling yang terstruktur ini membuat proses konseling lebih dipahami oleh konseli dan meningkatkan kemungkinan mereka mampu melakukan self-help di akhir sesi konseling.

Prinsip nomor 9: Cognitive-Behavior Therapy mengajarkan konseli untuk mengidentifikasi, mengevaluasi, dan menanggapi pemikiran disfungsional dan keyakinan mereka.

Prinsip nomor 10: Cognitive-Behavior Therapy menggunakan berbagai teknik untuk merubah pemikiran, perasaan, dan 
tingkah laku. Pertanyaan-pertanyaan yang berbentuk sokratik memudahkan konselor dalam melakukan konseling cognitivebehavior. Pertanyaan dalam bentuk sokratik merupakan inti atau kunci dari proses evaluasi konseling. Dalam proses konseling, CBT tidak mempermasalahkan konselor menggunakan teknik-teknik dalam konseling lain seperti teknik Gestalt, Psikodinamik, Psikoanalisis selama teknik tersebut membantu proses konseling yang lebih saingkat dan memudahkan konelor dalam membantu konseli. Jenis teknik yang dipilih akan dipengaruhi oleh konseptualisasi konselor tehadap konseli, masalah yang sedang ditangani, dan tujuan konselor dalam sesi konseling tersebut (Beck, 2011).

\section{METODE PENELITIAN}

Penelitian ini menggunakan desain penelitian Pre-eksperimentalyang dianggap sebagai eksperimen tidak sebenarnya sering disebut dengan istilah "Quasi Eksperimen".. Jenis Quasi Experimental yang digunakan dalam penelitian ini adalah Nonequivalent Control Group Design dimana kelas penelitian diberikan pretest $(\mathrm{O} 1)$ sebelum diberi perlakuan $(\mathrm{X})$ untuk mengetahui keadaan awal kedua kelas, kemudian setelah diberi perlakuan (X) kepada kelas eksperimen, diberikan posttest $(\mathrm{O} 2)$ untuk mengetahui sejauh mana perlakuan berpengaruh.

Tabel 1. Prosedur Penelitian

\begin{tabular}{ll}
\hline Kegiatan & Uraian Kegiatan \\
\hline Persiapan & $\begin{array}{l}\text { Peneliti mengajukan surat permohonan kepada } \\
\text { pihak SMK Negeri 1 Babelan dan meminta izin } \\
\text { kepada kordinator BK yaitu Joko Andrianto, }\end{array}$ \\
& S.Pd.
\end{tabular}

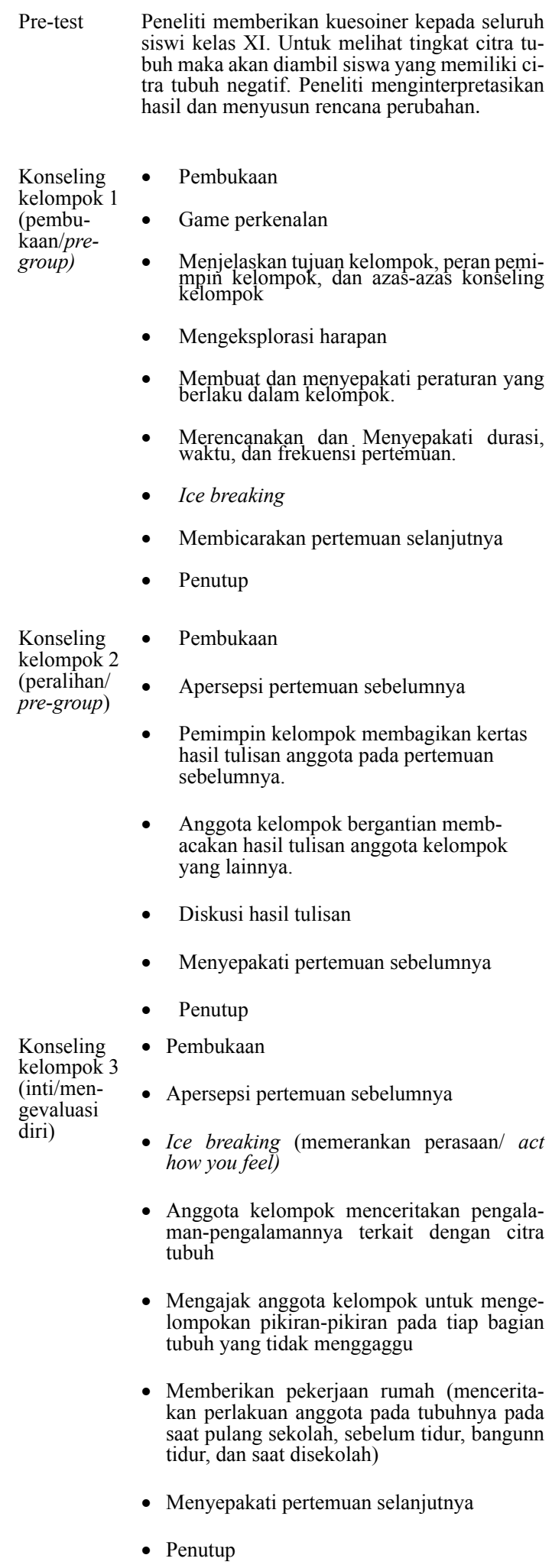
siswi kelas XI. Untuk melihat tingkat citra tubuh maka akan diambil siswa yang memiliki citra tubuh negatif. Peneliti menginterpretasikan hasil dan menyusun rencana perubahan.

Konseling kelompok 1 (pembukaan/pregroup) kelompok (peralihan/ pre-group)

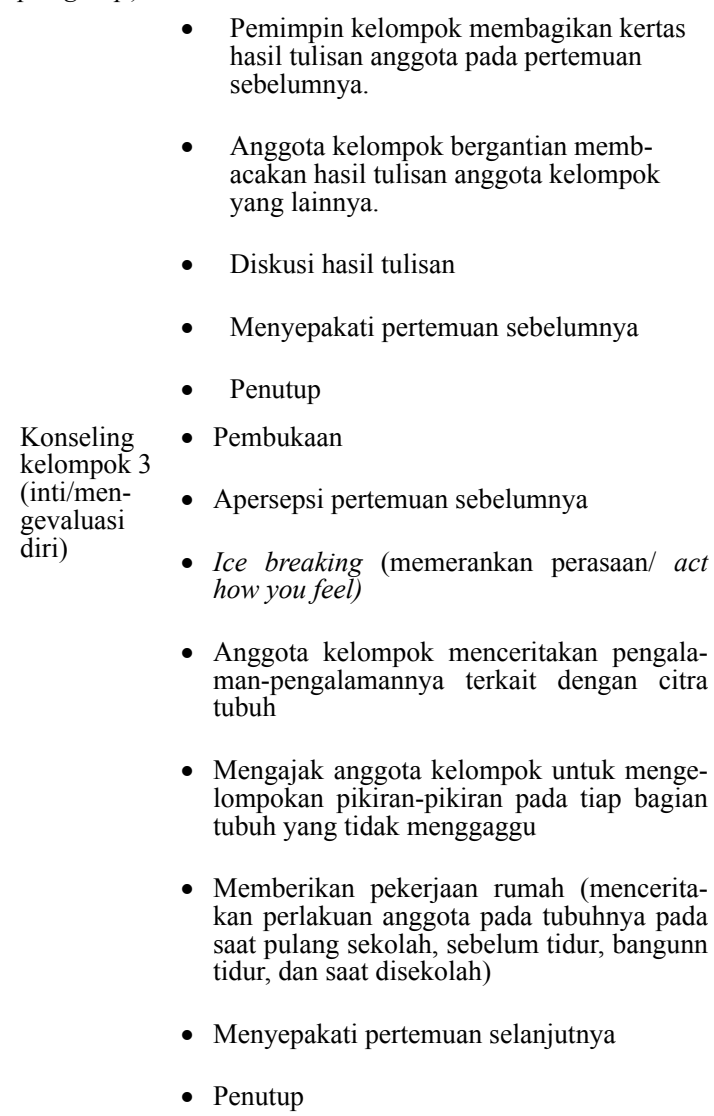




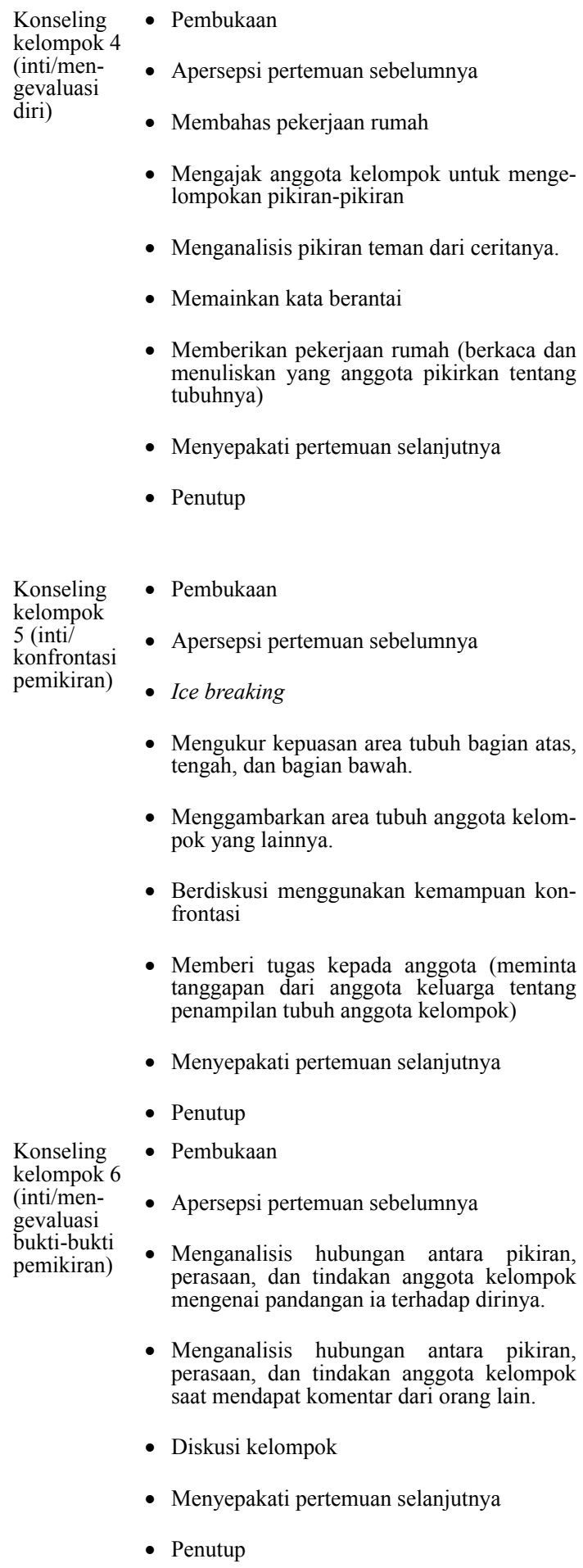

- Mengajak anggota kelompok untuk mengelompokan pikiran-pikiran

- Menganalisis pikiran teman dari ceritanya.

- Memainkan kata berantai

- Memberikan pekerjaan rumah (berkaca dan menuliskan yang anggota pikirkan tentang tubuhnya)

- Menyepakati pertemuan selanjutnya

- Penutup

Konseling

kelompok

5 (inti/

konfrontasi

pemikiran)

- Pembukaan

- Apersepsi pertemuan sebelumnya

- Ice breaking

- Mengukur kepuasan area tubuh bagian atas, tengah, dan bagian bawah.

- Menggambarkan area tubuh anggota kelompok yang lainnya.

- Berdiskusi menggunakan kemampuan konfrontasi

- Memberi tugas kepada anggota (meminta tanggapan dari anggota keluarga tentang penampilan tubuh anggota kelompok)

- Menyepakati pertemuan selanjutnya

- Penutup

Konseling

kelompok 6

(inti/men-

gevaluasi

bukti-bukti

pemikiran)

- Apersepsi pertemuan sebelumnya

- Menganalisis hubungan antara pikiran, perasaan, dan tindakan anggota kelompok mengenai pandangan ia terhadap dirinya.

- Menganalisis hubungan antara pikiran, perasaan, dan tindakan anggota kelompok saat mendapat komentar dari orang lain.

- Diskusi kelompok

- Menyepakati pertemuan selanjutnya

- Penutup

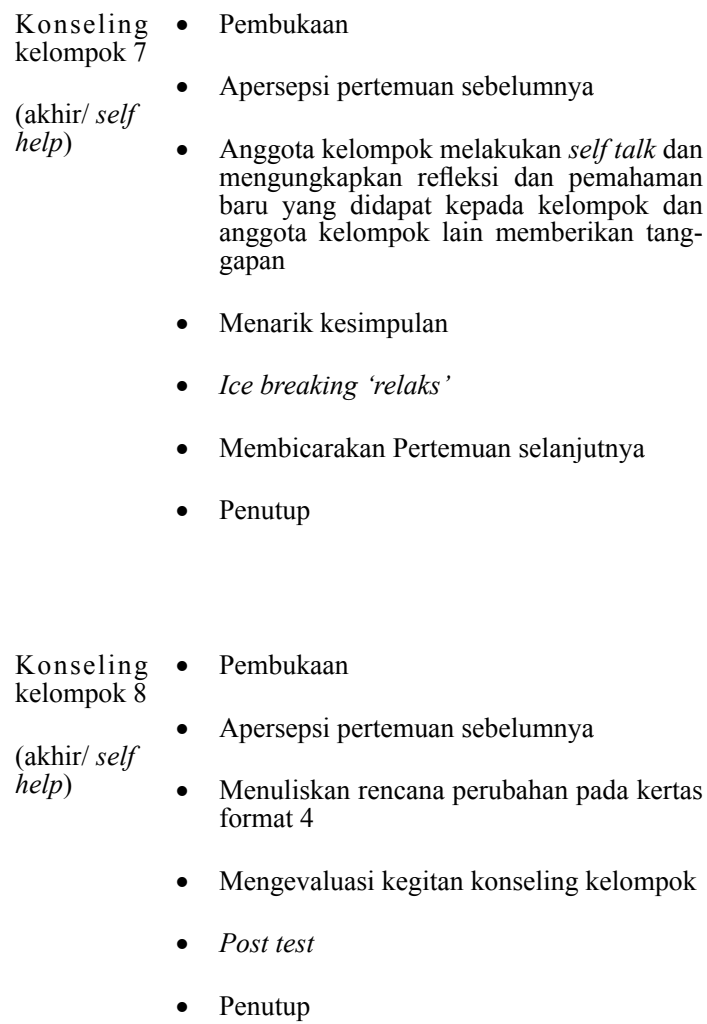

- Anggota kelompok melakukan self talk dan mengungkapkan refleksi dan pemahaman baru yang didapat kepada kelompok dan anggota kelompok lain memberikan tanggapan

- Menarik kesimpulan

- Ice breaking 'relaks'

- Membicarakan Pertemuan selanjutnya

- Penutup

Post-test Peneliti memberikan kuesioner kepada anggota kelompok treatment setelah diberikan perlakuan dan kelompok kontrol sebagai pembanding

\section{HASIL PENELITIAN}

Hasil pre-test kepada 107 siswi kelas XI di SMK Negeri 1 Babelan menunjukan hasil bahwa terdapat 44 siswi $(41,12 \%)$ berada pada kategori positif, 45 siswi $(42,5 \%)$ berada pada kategori netral dan 20 siswa $(18,7 \%)$ berada pada kategori negatif. Siswa dengan kategori body image negatif kemudian dijadikan sampel penelitian. Untuk membentuk kelompok kontrol dan treatment, peneliti mengambil 12 orang siswi dengan nilai terendah kemudian secara acak dipilih masing-masing 6 orang untuk memasuki kelompok treatment dan kelompok kontrol. 5 orang anggota kelompok treatment berada pada kategori negatif dan 1 orang berada pada kategori 
netral dan semua anggota kelompok kontrol berada pada kategori negatif. Kemudian setelah diberikan perlakuan hasil posttest menunjukkan terdapat perubahan frekuensi siswa pada setiap kategori. Siswa pada kelompok treatment mengalami peningkatan yaitu 1 orang dari kategori negatif ke positif, 1 orang dari kategori netral ke positif, 3 orang dari kategori negatif ke netral, dan 1 orang tetap pada kategori negatif. Sedangkan pada kelompok kontrol terdapat sedikit perubahan dimana terdapat 2 siswa yang meningkat dari kategori negatif ke netral dan 4 lainnya tetap pada kategori negatif.

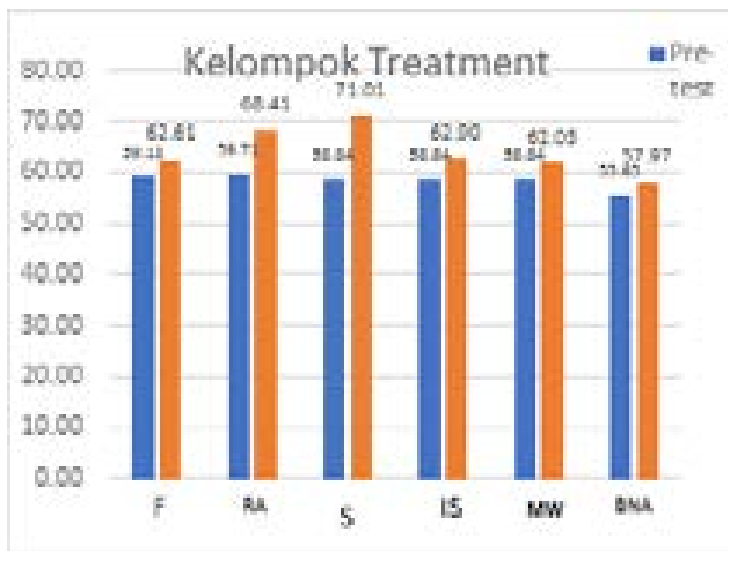

Grafik 1. Histogram Capaian Skor Body Image Kelompok Treatment

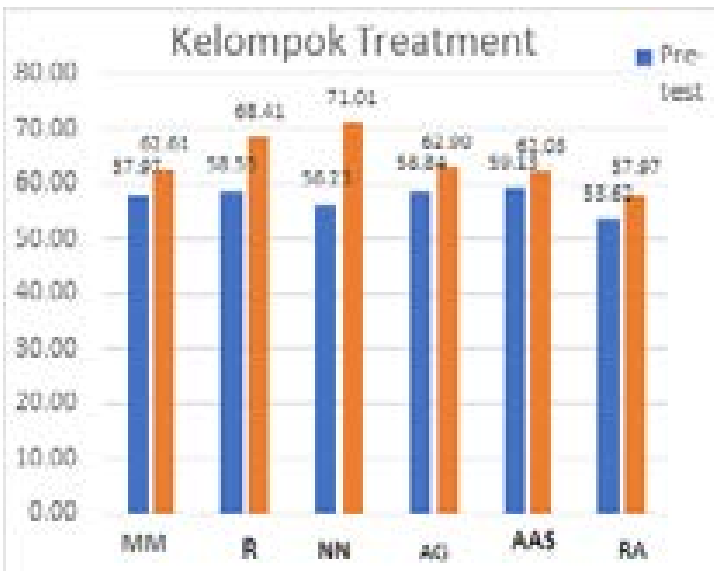

Grafik 2. Histogram Capaian Skor Body Image Kelompok Kontrol

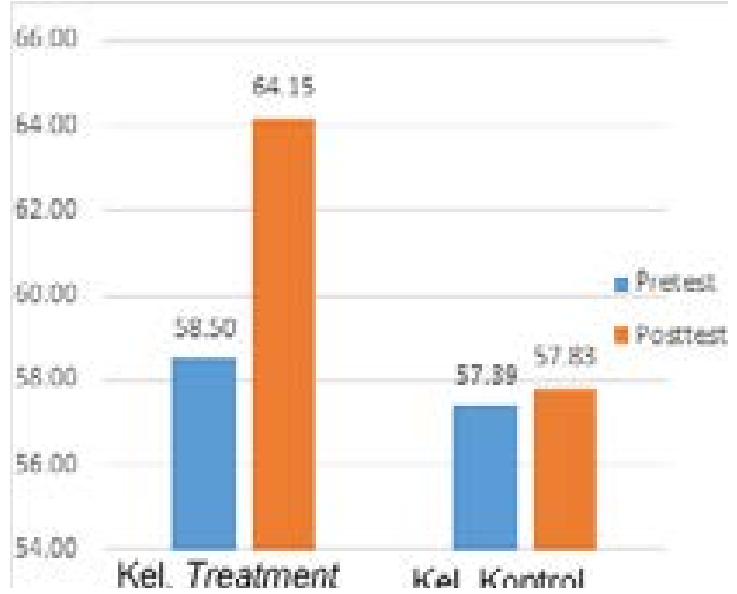

Grafik 3. Histogram Rata-rata Capaian Skor Body Image Kelompok

Tabel 1. Rata-rata Capaian Skor

\begin{tabular}{|c|c|c|c|c|c|c|}
\hline $\begin{array}{c}\text { Skor } \\
\text { rata-rata }\end{array}$ & $\begin{array}{l}\text { Skor } \\
\text { Ideal }\end{array}$ & $\begin{array}{l}\text { Pre- } \\
\text { test }\end{array}$ & $(\%)$ & $\begin{array}{c}\text { Post- } \\
\text { test }\end{array}$ & $(\%)$ & 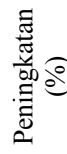 \\
\hline $\begin{array}{l}\text { Kelom- } \\
\text { pok } \\
\text { treatment }\end{array}$ & 345 & 201.83 & 58.50 & 221.33 & 64.15 & 5.65 \\
\hline $\begin{array}{l}\text { Kelom- } \\
\text { pok } \\
\text { kontrol }\end{array}$ & 345 & 198 & $\mathbf{5 7 . 3 9}$ & 199.5 & $\mathbf{5 7 . 8 3}$ & 0.44 \\
\hline
\end{tabular}

Rata-rata skor sebelum diberi perlakuan pada kelompok treatment yaitu sebesar 201.83 Sedangkan setelah diberikan perlakuan, ratarata skor meningkat 19.5 poin menjadi 221.33 . Dua anggota kelompok meningkat pada kategori positif, tiga anggota kelompok pada kategori netral dan 1 anggota kelompok tetap pada kategori negatif.

Sedangkan pada kelompok kontrol, rata-rata skor pre-test sebesar 198 dengan keseluruhan anggota berada pada kategori negatif. Ketika post-test, terdapat peningkatan rata-rata skor sebesar 1.5 poin menjadi 199.5. Dua anggota pada kelompok kontrol meningkat pada kategori netral dan empat anggota kelompok lainnya tetap pada kategori negatif. 


\section{KESIMPULAN}

Peneliti menyimpulkan hasil penelitian tentang pengaruh konseling kelompok dengan pendekatan body image cogtnitive behavior therapy terhadap citra tubuh negatif siswi SMK, sebagai berikut:

1. Data capaian skor menunjukkan bahwa semua siswi pada kelompok treatment mengalami peningkatan. Peningkatan tertinggi dicapai oleh $\mathrm{S}$ dengan persentase peningkatan sebanyak $12.17 \%$ sedangkan pada kelompok kontrol perubahan skor bervariasi yaitu terdapat 4 siswi mengalami peningkatan dan 2 siswi tetap.

2. Setelah dilakukan kegiatan konseling kelompok BI-CBT sebagai perlakuan pada kelompok treatment hasil posttest menunjukan terdapat 1 orang siswi yang beranjak dari kategori netral kepada kategori positif, 1 orang beranjak dari kategori negatif kepada kategori positif, 3 orang siswi beranjak dari kategori negatif kepada kategori netral dan 1 siswi tetap pada kategori negatif. Sedangkan pada kelompok kontrol, 2 siswa meningkat pada kategori netral dan 4 siswa lain tetap berada pada ketegori negatif.

3. Hasil uji dengan Wilcoxon signed ranks test pada kelompok treatment menunjukkan nilai dari Asymp. Sig (2-tailed) adalah sebesar 0.028 . Nilai probabilitas tersebut lebih kecil dari pada nilai signifikansi $\alpha=0.05$. Dengan demikian dapat dinyatakan bahwa secara signifikan terdapat peningkatan body image pada saat posttest dalam kelompok treatment. Sedangkan pada kelompok kontrol hasil uji dengan Wilcoxon signed ranks test menunjukkan nilai dari Asym. Sig (2-tailed) adalah sebesar 0.066. Nilai probabilitas tersebut lebih besar dari pada nilai signifikansi $\alpha=0.05$. Dengan demikian dapat dinyatakan bahwa tidak ada perbedaan tingkat body image siswa pada saat pretest dan posttest dalam kelompok kontrol. Sehingga dapat disimpulkan bahwa terdapat pengaruh layanan konseling kelompok BI-CBT terhadap body image negatif siswa kelas XI di SMK Negeri 1 Babelan.

\section{Implikasi}

Implikasi dari hasil penelitian yang telah dilakukan adalah kondisi citra tubuh siswi kelas XI di SMK Negeri 1 Babelan cukup baik dapat dilihat dengan hanya 20 dari 107 orang siswi yang memiliki citra tubuh negatif. kemudian konseling kelompok BI-CBT memiliki pengaruh terhadap citra tubuh negatif siswi kelas XI di SMK Negeri 1 Babelan. Persepsi citra tubuh yang negatif memiliki dampak pada menurunnya kepercayaan diri dan siswi. Dan setelah dilaksanakannya konseling kelompok siswi dapat mengetahui letak permasalahan yang menyebabkan mereka memiliki citra tubuh negatif sehingga siswi lebih mampu untuk menerima kondisi tubuhnya dan tampil lebih percaya diri.

Pelaksanaan konseling kelompok BICBT membantu siswi untuk mengeksplorasi perasaan yang selama ini tidak dapat mereka ungkapkan. Siswi yang telah mengikuti layanan konseling kelompok BICBT dapat mengetahui kelemahan dirinya dan menerima kondisi tubuhnya sekarang sehingga membuat mereka lebih berani untuk mengeksperikan penampilannya. Meskipun demikian citra tubuh juga dipengaruhi oleh faktor media massa dan hubungan interpersonal individu, maka kondisi citra tubuh siswi tersebut dapat berubah. Maka diperlukan tindak lanjut 
dan pengawasan terhadap siswi, sehingga apabila mereka mampu mengendalikan diri ketika berada pada kondisi yang membuat citra tubuh mereka menurun.

\section{Saran}

Saran yang dapat diberikan bagi Guru Bimbingan Konseling di Sekolah adalah mendeteksi dini siswi yang memiliki citra tubuh negatif dan segera dilakukan konseling dengan menggunakan instrumen MBSRQ atau instrumen yang relevan lainnya. Tindak lanjut terhadap siswa yang memiliki citra tubuh negatif tersebut diberikan layanan konseling individu atau konseling kelompok dengan menggunakan pendekatan body image cognitive behavioral therapy yang sudah teruji dalam beberapa penelitian dapat memperbaiki kondisi citra tubuh individu.

Saran yang dapat diberikan bagi Program Studi Bimbingan Konseling adalah mengasah kemampuan interpretasi hasil instrumen dan kemampuan pelaksanaan konseling kelompok. Terkait dengan penggunaan instrumen adaptasi diperlukan pemberian materi pada mata kuliah asesmen.

Mahasiswa yang akan melakukan penelitian adalah melakukan metode penelitian lanjut dari penelitian yang sudah dilakukan. Sehingga penelitian yang sudah ada akan semain berkembang. Peneliti yang akan menggunakan pendekatan cognitive behavioral therapy (CBT) maupun body image cognitive behavioral therapy (BICBT) harap menyusun prosedur intervensi penelitian dengan baik sehingga pemberian intevensi dapaat terlaksana sesuai dengan target

\section{DAFTAR PUSTAKA}

Cash, T.F. \& Pruzinsky, T. (2002). Body Image: A Handbook of Theory, Research, and Clinical Practice. New York: The Guilford Press.

Cash, T.F. (2000). The Multidimensional Body- Self Relation Questionnaire MBSRQ User's Manual 3rd Revision. Virginia. Old Dominion, University Norfolk.

Garber, N. (2015). Cognitive Behavioral Therapy and Body Image. EatingDisorderHope.com

Gayatri. (2011). Buku Cerdas untuk Perempuan Aktif. Jakarta: Gagas Media

Grogan.(1999). Body Image Understanding Body Dissatisfaction in Men, Women, and Children. London: Routledge.

Mahan, K. (2008). Krause's Food and Nutrition Therapy. Saunders/Elsevier

Mauludina, G. (2012). Pengaruh kelompok psikoedukasi dengan Cognitve Behavioral Therapy (CBT) Terhadap Body Image (Unpublished Undergraduated Thesis). Universitas Negeri Jakarta, Jakarta

Oemarjoedi, A.K. (2003). Pendekatan Cognitive Behavior dalam Psikoterapi. Jakarta: Kreativ Media.

Stuart G.W, \& Sundeen S.J. (1995). Principles and Practice of Psychiatric Nursing ed 5. Missouri: Mosby-Year Book, Inc. 
KISI-KISI INSTRUMEN BODY IMAGE

\begin{tabular}{|c|c|c|c|c|c|}
\hline \multirow{2}{*}{$\begin{array}{l}\overline{0} \\
\stackrel{0}{\pi} \\
\frac{\pi}{\pi}\end{array}$} & \multirow{2}{*}{ Aspek } & \multirow{2}{*}{ Indikator } & \multicolumn{2}{|c|}{$\begin{array}{l}\text { Macam-macam } \\
\text { Emosi }\end{array}$} & \multirow[t]{2}{*}{$\begin{array}{l}\text { Jml item } \\
\text { Valid }\end{array}$} \\
\hline & & & $\begin{array}{l}\text { Emosi } \\
\text { Positif }\end{array}$ & $\begin{array}{l}\text { Emosi } \\
\text { Negatif }\end{array}$ & \\
\hline \multirow{11}{*}{ 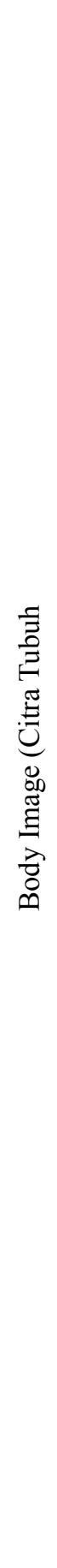 } & $\begin{array}{l}\text { Evaluasi penampilan } \\
\text { (appearance evalua- } \\
\text { tion) }\end{array}$ & $\begin{array}{l}\text { Mengukur perasaan menarik atau } \\
\text { tidak menarik, kepuasaan atau ketidak } \\
\text { puasaan terhadap penampilan seseo- } \\
\text { rang. }\end{array}$ & $\begin{array}{l}5,11,21 \\
30,39\end{array}$ & 42,48 & 6 \\
\hline & $\begin{array}{l}\text { Orientasi penampilan } \\
\text { (appearance orienta- } \\
\text { tion) }\end{array}$ & $\begin{array}{l}\text { Mengukur derajat perhatian individu } \\
\text { terhadap penampilannya. }\end{array}$ & $\begin{array}{l}1,2,12 \\
13,22 \\
31,41,50\end{array}$ & $\begin{array}{l}23,32 \\
40,49\end{array}$ & 12 \\
\hline & $\begin{array}{l}\text { Evaluasi kebugaran } \\
\text { (fitness evaluation) }\end{array}$ & $\begin{array}{l}\text { Mengukur derajat kebugaran yang } \\
\text { dirasakan individu terhadap fisiknya }\end{array}$ & 24,51 & 33 & 2 \\
\hline & $\begin{array}{l}\text { Orientasi kebugaran } \\
\text { fisik (fitness orienta- } \\
\text { tion) }\end{array}$ & $\begin{array}{l}\text { Mengukur derajat perhatian individu } \\
\text { terhadap kebugarannya atau kom- } \\
\text { petensinya dalam bidang olah raga } \\
\text { kebugaran. }\end{array}$ & $\begin{array}{l}3,4,14 \\
26,35,44 \\
53\end{array}$ & $\begin{array}{l}6,15 \\
16,25 \\
34,43\end{array}$ & 9 \\
\hline & $\begin{array}{l}\text { Evaluation kesehatan } \\
\text { (health evaluation) }\end{array}$ & $\begin{array}{l}\text { Mengukur penilaian individu menge- } \\
\text { nai kesehatan tubuhnya. }\end{array}$ & $7,27,54$ & $\begin{array}{l}17,36 \\
45\end{array}$ & 5 \\
\hline & $\begin{array}{l}\text { Orientasi kesehatan } \\
\text { (health orientation) }\end{array}$ & $\begin{array}{l}\text { Mengukur derajat pengetahuan dan } \\
\text { kesadaran individu terhadap pentin- } \\
\text { gnya } \\
\text { kesehatan fisik. }\end{array}$ & $\begin{array}{l}8,9,18 \\
19,29,52\end{array}$ & 28,38 & 7 \\
\hline & $\begin{array}{l}\text { Orientasi tentang } \\
\text { penyakit } \\
\text { (illness orientation) }\end{array}$ & $\begin{array}{l}\text { Mengukur derajat pengetahuan dan } \\
\text { reaksi individu terhadap berbagai } \\
\text { masalah penyakit yang dirasakan } \\
\text { tubuhnya. }\end{array}$ & $46,55,56$ & 37,47 & 3 \\
\hline & \multirow[t]{2}{*}{$\begin{array}{l}\text { Kepuasaan area } \\
\text { tubuh } \\
\text { (Body areas satisfac- } \\
\text { tion } \\
\text { scale) }\end{array}$} & $\begin{array}{l}\text { Kepuasan individu terhadap aspek-as- } \\
\text { pek tertentu dari penampilannya. }\end{array}$ & $\begin{array}{l}61,62 \\
63,64 \\
64,65 \\
66,67 \\
68,69\end{array}$ & & 9 \\
\hline & & $\begin{array}{l}\text { Menggambarkan persepsi seseorang } \\
\text { terhadap berat badannya, kecema- } \\
\text { san terhadap kegemukan, perhatian } \\
\text { terhadap berat badan, kecenderungan } \\
\text { melakukan diet untuk menurunkan be- } \\
\text { rat badan dan membatasi pola makan. }\end{array}$ & $\begin{array}{l}10,20 \\
57,58\end{array}$ & & 1 \\
\hline & \multirow[t]{2}{*}{$\begin{array}{l}\text { Pengkategorian uku- } \\
\text { ran tubuh (selfclassi- } \\
\text { fied weight) }\end{array}$} & $\begin{array}{l}\text { Menggambarkan bagaimana seseo- } \\
\text { rang pempersepsi dan menilai berat } \\
\text { badannya. }\end{array}$ & 59,60 & & 2 \\
\hline & & Total Item Valid & & & 56 \\
\hline
\end{tabular}


Kuesioner Citra Tubuh (Body Image)

Nama Lengkap :

Kelas

:

Usia

Etnis

Perkenalkan nama saya Nurul Fazriah mahasiswa program studi Bimbingan dan Konseling di Universitas Negeri Jakarta angkatan 2012 Saat ini saya sedang mengerjakan skripsi dengan judul "Pengaruh Konseling Kelompok Pendekatan Body Image-Cognitive Behavioral Therapy (BI-CBT) terhadap Citra Tubuh Siswi SMK" dibimbing oleh Dr. Susi Fitri, S.Pd, M.Si, Kons. sebagai dosen pembimbing utama dan Dr. Aip Badrudjaman, M.Pd. sebagai dosen pembimbing pendamping.

Saya ingin meminta bantuan dari adik-adik untuk mengisi instrumen penelitian terkait citra tubuh sesuai dengan petunjuk yang telah disediakan.

\section{Petunjuk Pengisian:}

2. Bacalah dengan cermat dan saksama tiap butir pernyataan

3. Pilih salah satu dari lima alternatif jawaban dengan memberikan tanda silang (X) pada kolom yang disediakan

4. Tidak ada jawaban benar atau salah. Berikan jawaban yang menurut anda paling tepat. Ingatlah, jawaban anda bersifat rahasia jadi anda dapat menjawab semua pertanyaan dengan jujur.

Terimakasih atas partisipasi dan waktu luang yang anda berikan untuk mengisi kuesioner ini.

- Silanglah kolom STS, jika anda Sangat Tidak Setuju dengan pernyataan tersebut

- Silanglah kolom TS, jika anda Tidak Setuju dengan pernyataan tersebut

- Silanglah kolom R, jika anda antara Setuju dan Tidak Setuju dengan pernyataan tersebut

- Silanglah kolom S, jika anda Setuju dengan pernyataan tersebut

Silanglah kolom SS, jika anda Sangat Setuju dengan pernyataan tersebut

Contoh pengisian:

\begin{tabular}{|c|c|c|c|c|c|c|}
\hline NO & Pernyataan & STS & TS & $\overline{\mathbf{R}}$ & $\mathbf{S}$ & SS \\
\hline [nsib: & 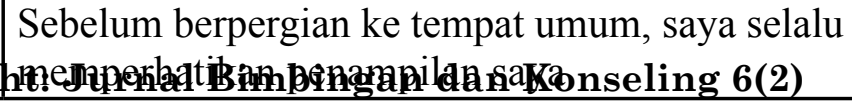 & & & Des & $\begin{array}{l}\mathrm{X} \\
\text { mber }\end{array}$ & 2017 \\
\hline
\end{tabular}

*Bila anda selalu memperhatikan penampilan saat akan bepergian, berilah tanda (X) pada kolom Sangat Setuju (SS) 


\begin{tabular}{|c|c|c|c|c|c|c|}
\hline NO & Pernyataan & STS & TS & $\mathbf{R}$ & $\mathbf{S}$ & SS \\
\hline 1 & $\begin{array}{l}\text { Sebelum berpergian ke tempat umum, saya selalu } \\
\text { memperhatikan penampilan saya }\end{array}$ & & & & & \\
\hline 2 & $\begin{array}{l}\text { Saya cermat dalam membeli pakaian yang akan } \\
\text { membuat saya terlihat berpenampilan terbaik }\end{array}$ & & & & & \\
\hline 3 & $\begin{array}{l}\text { Saya akan lulus pada hampir seluruh tes kebuga- } \\
\text { ran tubuh }\end{array}$ & & & & & \\
\hline 4 & $\begin{array}{l}\text { Penting bagi saya untuk memiliki kekuatan fisik } \\
\text { yang sangat baik. }\end{array}$ & & & & & \\
\hline 5 & $\begin{array}{l}\text { Saya memiliki penampilan tubuh yang menarik } \\
\text { secara seksual }\end{array}$ & & & & & \\
\hline 6 & Saya tidak berolahraga secara teratur & & & & & \\
\hline 7 & Saya dapat mengendalikan kesehatan saya & & & & & \\
\hline 8 & $\begin{array}{l}\text { Saya mengetahui banyak hal yang dapat mempen- } \\
\text { garuhi kesehatan fisik saya. }\end{array}$ & & & & & \\
\hline 9 & Saya dengan sadar menerapkan gaya hidup sehat & & & & & \\
\hline 10 & Saya selalu khawatir menjadi gemuk & & & & & \\
\hline 11 & Saya menyukai penampilan seperti apa adanya & & & & & \\
\hline 12 & $\begin{array}{l}\text { Saya memeriksa penampilan di cermin kapanpun } \\
\text { saya bisa }\end{array}$ & & & & & \\
\hline 13 & $\begin{array}{l}\text { Sebelum keluar rumah atau berpergian biasanya } \\
\text { saya menghabiskan banyak waktu untuk ber- } \\
\text { siap-siap }\end{array}$ & & & & & \\
\hline 14 & Ketahanan fisik saya tergolong baik & & & & & \\
\hline 15 & $\begin{array}{l}\text { Berpartisipasi dalam kegiatan olahraga tidak pent- } \\
\text { ing bagi saya }\end{array}$ & & & & & \\
\hline 16 & $\begin{array}{l}\text { Saya tidak berusaha menjaga kebugaran fisik } \\
\text { secara rutin }\end{array}$ & & & & & \\
\hline 17 & $\begin{array}{l}\text { Kondisi Kesehatan saya adalah hal yang tidak } \\
\text { dapat diperkirakan, kadang- kadang baik atau } \\
\text { buruk }\end{array}$ & & & & & \\
\hline 18 & $\begin{array}{l}\text { Kesehatan yang baik adalah salah satu hal yang } \\
\text { terpenting dalam kehidupan saya }\end{array}$ & & & & & \\
\hline 19 & $\begin{array}{l}\text { Saya tidak melakukan hal-hal yang dapat men- } \\
\text { gancam kesehatan saya }\end{array}$ & & & & & \\
\hline 20 & $\begin{array}{l}\text { Saya sangat sadar jika ada perubahan berat badan } \\
\text { sekecil apapun }\end{array}$ & & & & & \\
\hline 21 & $\begin{array}{l}\text { Kebanyakan orang menganggap bahwa penampi- } \\
\text { lan tubuh saya menarik }\end{array}$ & & & & & \\
\hline
\end{tabular}




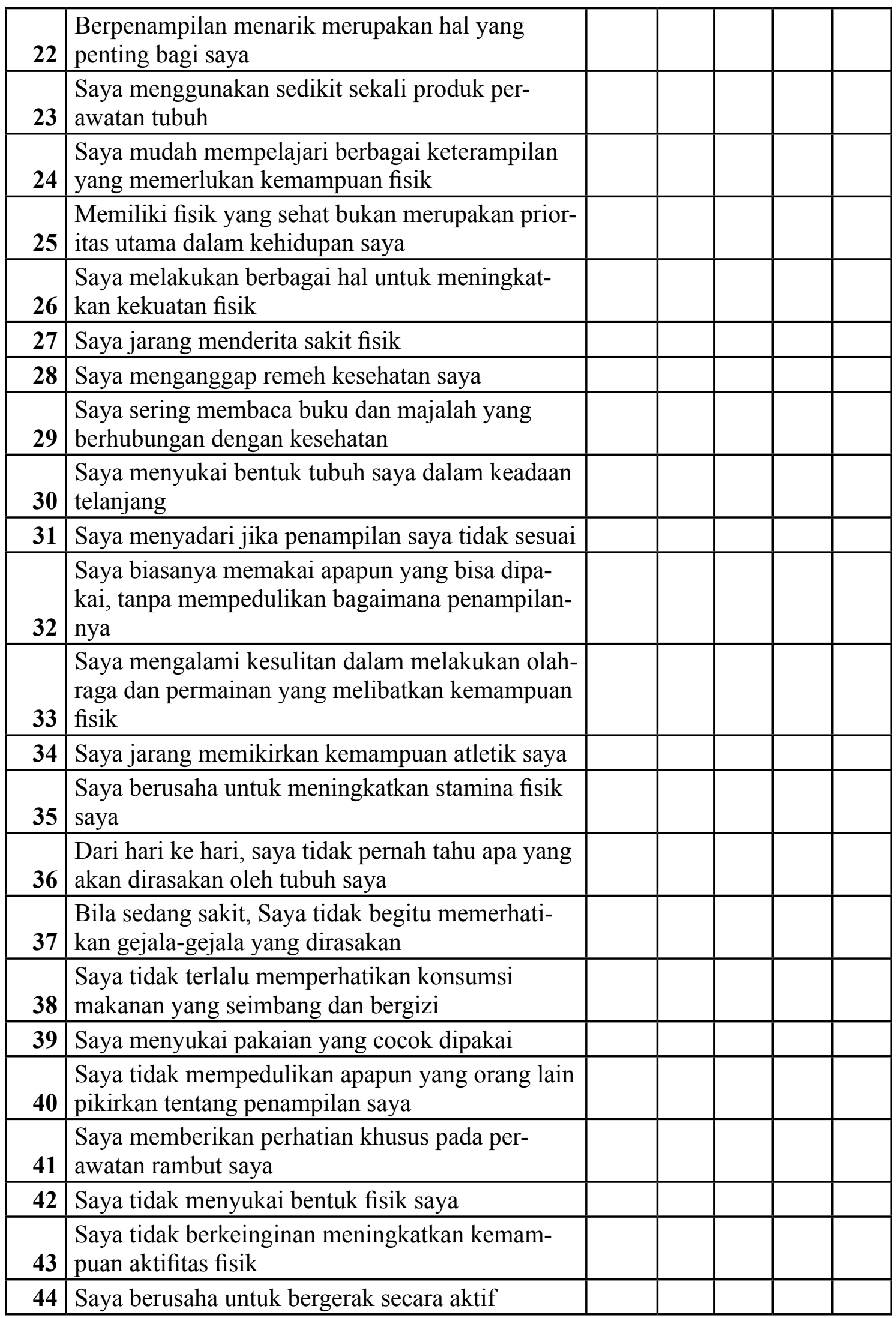




\begin{tabular}{|r|l|l|l|l|l|l|}
\hline $\mathbf{4 5}$ & Saya mudah terserang penyakit & & & & & \\
\hline $\mathbf{4 6}$ & $\begin{array}{l}\text { Saya memperhatikan gejala penyakit dalam tubuh } \\
\text { saya }\end{array}$ & & & & & \\
\hline $\mathbf{4 7}$ & $\begin{array}{l}\text { Apabila saya terserang demam atau flu, Saya } \\
\text { mengabaikannya dan tetap melakukan aktivitas } \\
\text { seperti biasa }\end{array}$ & & & & & \\
\hline $\mathbf{4 8}$ & $\begin{array}{l}\text { Menurut saya, saya bukan orang yang menarik } \\
\text { secara fisik }\end{array}$ & & & & & \\
\hline $\mathbf{4 9}$ & $\begin{array}{l}\text { Saya tidak pernah memikirkan tentang penampi- } \\
\text { lan saya }\end{array}$ & & & & & \\
\hline $\mathbf{5 0}$ & $\begin{array}{l}\text { Saya selalu berusaha untuk memperbaiki } \\
\text { penampilan fisik }\end{array}$ & & & & & \\
\hline $\mathbf{5 1}$ & Saya dapat mengatur hidup saya dengan baik & & & & & \\
\hline $\mathbf{5 2}$ & $\begin{array}{l}\text { Saya mengetahui banyak hal tentang kesehatan } \\
\text { dan kebugaran tubuh }\end{array}$ & & & & & \\
\hline $\mathbf{5 3}$ & $\begin{array}{l}\text { Saya melakukan olahraga secara teratur sepanjang } \\
\text { tahun }\end{array}$ & & & & & \\
\hline $\mathbf{5 4}$ & Saya memiliki tubuh/fisik yang sehat & & & & & \\
\hline $\mathbf{5 5}$ & $\begin{array}{l}\text { Saya sangat sadar akan perubahan sekecil apapun } \\
\text { dalam kesehatan tubuh saya }\end{array}$ & & & & & \\
\hline $\mathbf{5 6}$ & $\begin{array}{l}\text { Ketika muncul gejala penyakit, saya langsung } \\
\text { berobat }\end{array}$ & & & & & \\
\hline $\mathbf{5 7}$ & $\begin{array}{l}\text { Saya sedang menjalani program diet untuk } \\
\text { menurunkan berat badan }\end{array}$ & & & & & \\
\hline
\end{tabular}

Untuk pernyataan di bawah ini (nomer 58 - 60), lingkari angka di depan jawaban yang paling menggambarkan diri anda

1. Saya pernah mencoba berpuasa atau diet ketat untuk menurunkan berat badan

1. Tidak pernah

2. Jarang

3. Kadang-kadang

4. Sering

5. Sangat sering

2. Saya berpikir bahwa saya adalah orang yang:

1. Sangat kurus

2. Agak kurus 
3. Berat badan normal

4. Agak kelebihan berat badan

5. Sangat kelebihan berat badan

3. Orang yang melihat saya akan berpikir saya adalah seseorang yang:

1. Sangat kurus

2. Agak kurus

3. Berat badan normal

4. Agak kelebihan berat badan

5. Sangat kelebihan berat badan

Untuk pernyataan no. 61 - 69, tunjukkan besarnya kepuasan atau ketidakpuasan terhadap berbagai area dari tubuh anda, dengan memberikan tanda silang (X) pada salah satu dari lima pilihan jawaban

\begin{tabular}{|l|l|l|l|l|l|l|}
\hline No & Pernyataan & $\begin{array}{l}\text { Sangat } \\
\text { tidak } \\
\text { puas }\end{array}$ & $\begin{array}{l}\text { Tidak } \\
\text { puas }\end{array}$ & Netral & Puas & $\begin{array}{l}\text { San- } \\
\text { gat } \\
\text { puas }\end{array}$ \\
\hline $\mathbf{6 1}$ & $\begin{array}{l}\text { Wajah (bentuk wajah, warna kulit } \\
\text { wajah) }\end{array}$ & & & & & \\
\hline $\mathbf{6 2}$ & Rambut (warna, ketebalan, tekstur) & & & & & \\
\hline $\mathbf{6 3}$ & $\begin{array}{l}\text { Tubuh bagian bawah (bokong, } \\
\text { pinggul, paha, kaki) }\end{array}$ & & & & \\
\hline $\mathbf{6 4}$ & $\begin{array}{l}\text { Tubuh bagian tengah (pinggang, } \\
\text { perut) }\end{array}$ & & & & & \\
\hline $\mathbf{6 5}$ & $\begin{array}{l}\text { Tubuh bagian atas (payudara, bahu, } \\
\text { tangan) }\end{array}$ & & & & & \\
\hline $\mathbf{6 6}$ & Bentuk otot & & & & & \\
\hline $\mathbf{6 7}$ & Berat badan & & & & & \\
\hline $\mathbf{6 8}$ & Tinggi badan & & & & & \\
\hline $\mathbf{6 9}$ & Keseluruhan penampilan & & & & & \\
\hline
\end{tabular}

_TERIMAKASIH SUDAH MENJAWAB DENGAN JUJUR_ 